\title{
The Modern Mind, Religion, and the Spiritual in the Thinking of Frank C. Doan
}

\author{
Simuț Ciprian \\ Emanuel University of Oradea \\ ciprian.simut@emanuel.ro
}

\begin{abstract}
The problem of modernism presented itself as a challenge to traditional Christianity. It argued in favor of different values, both human, as well as spiritual, that came into conflict with what Christianity had known up to that point. Frank C. Doan is one of the thinkers who spoke in favor of the spiritual and the need of this realm for the true seeker of the eternal. He also spoke against any kind of exagerations and obsolete forms of religion/spiritualty/preaching that were present in Christianity at the beginning of the XXth century. This article presents the way he Doan argued in favor of the spiritual, to the detriment of the materialist way of life, as well as a comparison with certain thinkers of his own time, some modernists, others traditionalists. The essay brings forth a century old set of arguments in order to aid the contemporary thinker and believer in setting forth a personal and better informed way of thinking about the historical heritage of religion in general and Christianity in particular.
\end{abstract}

Keywords: modernism, religion, Christianity, heritage, preaching

\section{Introduction}

\section{The Genuine Manhood}

At the turn of the XXth century the modernist movement saw a set of books that argued in a modernist manner about religion in general, and Christianity in particular. The presented ideas argued in favor of a bigger picture than that presented to that point. He ideas presented by Frank C. Doan argue in favor of Christians looking at a bigger picture than that they had known until then. It is important for the contemporary believer and religious thinker to look back at the historical heritage of religious modernist thought, in order to better assess the present state of religion and Christianity.

The 'Preface' of Doan's book is essential for understanding the way he organized the chapters within it. The essays were delivered on various occasions, from lectures before students, to the Billings Lectures for the American Unitarian Association. In spite of various locations and dates, the essays are about religion and its place in modern society. Religion, God, God-Man, and larger Life are terms used by Doan to express what and how religion works in itself, but also how it is perceived by the early XXth century modern man. From these terms I would consider 'God-Man' as most important in relation to what conservative or traditional Christianity is. This concept will be encountered in the first chapter of his book 'Religion and the Modern Mind', which will be analyzed in the following paper. First of all, God-Man is an experience. Doan explains that in order to have this experience, one must

'strip your manhood most scrupulously, most painfully bare of all its filthy parts, to lay aside your bestialities and liberate your manhoods, to expose the naked, cold-as-steel soul of you to the eternal tempering energy of the world's fire-dust; then by reacting to transpierce the universe's self with this pure and strong manhood you bear, and call the resulting experience God, God-Man, Man-God, or by what name soever God may will. That experience is your religion's sole deep concern. That experience is you; it is God.' (Doan, 1909, p. v)

Such ideas are rather puzzling, at least for those of us who come from a traditional line of theological interpretations - such as the reformed Baptist (The Baptist confession of faith, 1765) - of the relationship between God and man. God is seen as outside creation, but also within it, but not one with it. God is transcendent and personal, but also personally involved in the life of man. The Christian religion encourages the creation of moral life, but in an automatous manner. This is due not too the fact that God is seen in Christianity as a law giver, but at as a Spirit giver, therefore, Christianity is not a religion of law, but a religion of Spirit (Evans, 1911, p. 431). Doan's perspective does not cancel the existence of God, but it morphs into a connection within man. He puts a strong emphasis on primordial reactions and feelings in order to describe the religious life of man, in connection to what/who God is. He argues that the image of God is shaped by one's age. The God of the 
young is enthusiastic, whimsical, and shallow, while the God of the old is aged, level-headed, and senile (Doan, 1909, p. vi). In order to get passed such negatives and reach the universal true religious feeling one must revert to temperament and the freshness of one's soul, regardless of age. 'Perpetual youth against congenital agedness' is the fundamental essence of conflict between man of different generations (Doan, 1909, p. vi). If one considers the description of God in light of man's image, this is a conflict between gods. The accusation can be that since man created God, he gave it spiritual qualities greater than the one's man possesses, but this God has also a low animal nature, such as that of man (Macculoch, MCMVIII, p. 76). Wisdom is acquired in time and Doan argues in favor of a constant critical reassessment of one's beliefs. This means that if at a younger age some things are considered shallow, but at a latter age are considered valuable, it means one is destroying one's soul and humanity. That would equate to blasphemy against the One Doan calls God. In this context, the God/God-Man of Doan is one of 'everlasting youth and perpetually buoyant Life' (Doan, 1909, pp. viii-xix).

\section{The Use and Abuse of Religion}

The first chapter of his book is entitled 'Religion and the modern mind' and it begins with an expected question: what is the place of religion in modern life? Before answering the question, Doan marks the fact that for over twenty five years the question had been posed and answered so many times from all sorts of weak points of view, that it became annoying for the a true modern mind. The book where he writes this remark was published in 1909, but the speech itself had been given in previous years. The problem is that the issue of church and human life is real, but the way it was handled lead to contempt for the honest, truth seeking people (Doan, 1909, p. 1).

The issue at hand is that the arguments in favor of keeping religion in the modern world are 'too secular; or too apologetic; or too defensive; or, if you please, too practical' (Doan, 1909, p. 1). This perspective argues in favor of balancing the purely spiritual aspect of reality with the practical one. There should not be too much of any of one in the detriment of another. Forcing the simple, clear truth of the spiritual realm with fabricated and excessively rational arguments brings no benefit to the genuine modern man. There is a need of the theoretical/doctrinal element, in order for the practical aspects of the religious life to make any sense at all (McComb, 1910, p. 18). Doan does not deny the need for the practical aspects of the spiritual and he does not deny that the spiritual has practical aspects, but he criticizes forcing the argument in favor of the practical side. Doan speaks, in this context, for a healing element for such deviations, namely a 'revival of those eternal verities in which all men of whatever culture have always instinctively believed' (Doan, 1909, p. 1). Such an approach flattens the spiritual to a universal kind and to a universal way of basic experience.

Doan's point argues in favor of a spiritual realm that can be sensed and experienced in the same way - at least at a basic, primordial level - by all humanity, without exception. The church becomes a simple, but quite important, 'distributer of the bread of life, of the pulpit as a place of moral and prophetic vision' (Doan, 1909, p. 1). The purpose of the church is not to indoctrinate, but to present and transpose the spiritual into the life of the believers via the message of the pulpit. The other problem is that the pulpit becomes too mundane, too ordinary. It lacks the 'spaciousness of the New Testament', putting a far too great emphasis on duty, but leaves God outside. Thus, the church lives in an environment it created, with no valuable and deep motives (Jackson, n.d., p. 78).

The bread of life can refer to Christ Himself as an exposer of the spiritual realm, as well as a materialization of a spiritual reality in the Eucharist. I must admit that the later perspective is a personal one and a slight exaggeration of the first. If the spiritual realm can be explained through language, thus offering meaning to the words that make up ideas, it is proper to argue in favor of the pulpit as a promoter of moral values and warnings against evil actions. The prophetic aspect of the pulpit is not related to the idea of some sort of direct dialogue with God, but a refined understanding the spiritual and a capacity of taking meanings from this realm and explaining them in plain language, but with great authority. If man is a spiritual being, than Christianity, in spite of a larger package of common themes shared with other religions, is set apart by the intrinsic values promoted by Christ. Man is to act in accordance with an disinterested love of God (Macculoch, MCMVIII, p. 93). Doan argues that people, or in his case the genuine modern man, desires the spiritual, as well as the church. There is no inconsistency between modern man and religion, one does not exclude the other. Modern man desires to know as much about reality as possible. This desire includes the spiritual. In spite of this desire, the modern man will reject any exaggeration, any theatrical, any dogmatic approach or explanation of the spiritual and religion. In Doan's own words: 'put it for him frankly, unaffectedly, above all undogmatically, and he will bow his assent' (Doan, 1909, p. 1). Modern man needs the spiritual, but he will reject the traditional way in which it is presented. In other words, modern man needs a natural, 
human/humane, clear, genuine presentation/explanation/dialogue on the subject of the spiritual and religion. If he feels truth and sincerity, Doan believes that modern man will not only accept, but bow his assent. The truth of the spiritual does not reside in one's affections and affectionate manner in which one presents it, but the meaning of the arguments.

The battle between truth and fiction was expressed vividly by Mr. Garrick in a dialogue with a minister, who asked him why was that those who talk of fiction gain huge crowds, while those who preach the truth have a small attendance. The answer was quite poignant: 'you preach truth as if it were fiction; and we deliver fiction as if it were truth' (The Quarterly Christian Spectator, 1833, p. 518). This was in 1833, but in a dialogue between Doan and a certain Mr. Pratt, he asks the later on what he should tell the students preparing for the ministry. Doan marks the words of Mr. Pratt as saying that 'since religion is the profoundest instinct, the deepest concern of human being, to be its sponser before men is indisputably a man's most sacred calling' (Doan, 1909, p. 2). However, Doan continues the words of Mr. Pratt, who ended his thought with a quotation - possibly from the 1833 The Quarterly Christian Spectator - 'he preaches the truth as if it were fiction!' It is not the full quotation from the Quarterly, but it is a reference to the modern minister, who preaches in such a way.

In spite of the massive amount of information from previous centuries of Christian doctrine, history, and various teachings, Doan argues in favor of using these in a 'simple and passionate emphasis of eternal truth' (Doan, 1909, p. 2). When talking about the practical side of arguing in favor of religion to the modern man, Doan refers to forcing the argument simply on the side of making the church a 'vital power in the lives of men' (Doan, 1909, p. 2). In another book on the subject of religion and the modern man, J. Macbride Sterrett - a pastor in the Protestant Episcopal Church - argues that the real modern man acknowledges the heritage of the past ages and uses them not as a slave, but as a competent and mature critic, searching the good and the valuable, in order to prosper the present and prepare the future (Macbride Sterrett, 1922, p. 16). Unlike the advice of Sterrett and the appeal to common sense of Doan, those he calls 'religion's ill-advised promoters' are suggesting churches should give up certain types of architecture, such as medieval, in order to adopt the style of modern buildings, with the sole purpose to make people feel more at home. Doan also marks that the church is ill-advised to serve man in one's needs, from food to spiritual matters. Entertainment is not forgotten and the ill advice is to transform the church into the mirror of modern forms of entertainment, because it cannot compete with the theater or the concert hall. The political sphere is also included and here the advice is in favor of a model of Christian Socialism. He does not explain in great detail these changes, but he proves to be greatly irritated by such puerile and futile modifications, to the detriment of religious values and honest spiritual quest (Doan, 1909, p. 3). Religion should be more than the external forms that symbolize the spiritual world. A church building is the result of a certain type of theology, which is the result of a certain type of exegetical interpretation. For Christianity they both stem from the same book, the Bible. The problems appear when the pulpit and the buildings are considered the essence of what people from outside should adhere to, not the message that is received, evaluated and then accepted.

The tragedy for the church, and implicitly for Christianity is the remark made by one of Doan's friends. This friend, a psychologist of religion, argued two extremes. First he believed that the days when priests could impose an external authority on the lives of men are now dead. Doan calls these dead influences 'hocus-pocus' days (Doan, 1909, p. 3). The office of the priest, the pulpit, and the church itself do not and should not command political or social authority in the form of dominion over the lives and freedoms of men. Authority in religion should be personal. There must be no hindrance between man and God. Christianity works of principle of direct authority upon man, by God, with no mediation, except the direct work of Christ (Butler, 1922, p. 135). However, Doan presents the other extreme that his friend goes into, namely that all that is left for the church is to transform itself into a sort of club, which would debate the 'deep and eternal concerns of life' (Doan, 1909, p. 3). The power of the church is thus leveled. Besides the debates on the eternals, the church is of no use to mankind. With this perspective Doan cannot agree, since he believes strongly in the presence and the existence of the spiritual realm, which is manifested, in the case of Christianity, through the pulpit prophecy and the moral teachings.

The harm done by the ill-advisors is ever groaning, due to the perspective the offer the members of the churches, namely that their church is dying and there is an honest need to revive it. The very thing that should bring people a message about the connection between the spiritual and the physical is that which has been perverted, the sermon. Doan reiterates that a practical sermon does little good to the church, unless coupled to mature explanations of dogma, or the teachings of the church. He points to the fact that those who argue in favor of an excessively practical sermons believe that the congregation is unable to understand the doctrine or the creed - the very identity of a denomination. Christianity would be reduced literally to a club, with no basic, fundamental values that would transcend the human condition. The use of the practical side of sermons is aimed, together with theoretical part, to feed the soul of man. Doan calls this the 'milk of truth', from the Biblical 
text. The theoretical and the practical do not exclude one another. They should be in harmony, for all the theory must find its place in the practical. In other words, any explanation of the spiritual realm, must find an application in every-day life (Doan, 1909, p. 4).

\section{Religion and Church}

Doan explains that religion and the Church should not be overlapped. He underlines that religion and the institution of the Church should not be overlapped. There should not be an overlap between religion and a specific denominational theory. According to Doan the 'eternal impulses of religion' are fear, faith, love and 'the like' (Doan, 1909, p. 5). These must not be confused with an institution of whatever sort. Modernists argue in favor of an immanent God, who reveals himself to man continuously, with no interruption, while the church argues that God transcends man's ability to understand him, thus 'God reveals himself only through means transcending reason, dramatically, in signs and wonders and it rests all religious authority in the hierarchy of the church, a constituted custodian and interpreter of the supernatural revelations' (Torrey, 1910 , p. 26) These impulses are not characteristic only to Christians, but to all humanity from the beginning. They were not developed as humans created culture, but are at the very essence what human being is. These impulses were not used by the church/es to further and better the human condition and human existence, in the manifestation of, culture, for example. Doan resorts to the knowledge of any historian, according to which the church has been a stumbling block for civilization. First of all fear is not something to give up, because it has its precise place in relation to the spiritual. Man fears the unknown, and if the unknown reveals itself under any form, fear is not an equal of terror, but it takes the form of deep respect. According to Doan the church has managed too many times to block the religious impulses of fear, love, and faith, due to institutional interests. The marriage between church and state did lead to an obstruction of care for the average human being, to the benefit of the institution (Doan, 1909, p. 5). Therefore, the church/es should acknowledge man in one's spiritual aspect as well. The institution of the church should never be more important than the individual, or the body of believers that make up a certain denomination. If the church is to fulfill its role as a shaper of civilization and a careful attendant to the needs, both spiritual and physical, of mankind, it must submit to acknowledging the importance of the individual, as well as the congregation/s. The idea that the church, as an institution, through its leaders, is actively teaching the congregants/believers, is not new (Finlay, 1917, p. 149), but the level of authority it has over one's life varies and it should be revisited repeatedly.

The church, as an institution, has been going against civilization also by the wrong use of the dogmas. Doan argues that the church, in its useless conflict with the sciences and philosophy, lost the 'instrumentalities of civilization and enlightenment' (Doan, 1909, p. 5). Needless to say that according to Doan is thoroughly against the dogmas that drown or negate the living impulse of religion. Dogma itself does not appear to be the problem, but the institution of the church that has put dogma before man and one's primordial religious instincts. Also, Doan, makes a most sorrowful observation, namely that the church as an institution of dogma is dead (Doan, 1909, p. 6). The modern mind cannot and will not work with such an institution, due to the fact that modernity looks for truth beyond the visible realm, even beyond an administrator of the spiritual realm, such as the church. The modern man looks within and without to understand reality and the spiritual reality, but there cannot be any obstruction from such institutions as the church, for example. Any such institution must be in harmony with the transcendent character of the spiritual realm, which is transposed in the form of religion and religious feelings. Christ created spiritual life and the church is the natural result. However, man is left to decide how the church is organized and how it is to be administered (Evans, 1911, p. 432).

In spite of the good reputation of the genuine modern man, Doan does admit that not all modern men are alike. There is no single relation between all modern men and religion. Modern men differ amongst themselves and men, in general, are completely different. However, Doan reduces the argument to those whom he calls modern men. In spite of the fact that not all men are in a perfect single relation to the church, as Doan notes, there is a predominant way of interacting with religion. He notes three types of people with whom he interacted, which he calls indifferent, confused and modern (Doan, 1909, p. 7).

\section{The Indifferent, the Confused, and the Modern Man}

The indifferent mind, for Doan, is represented by people who renounced religion altogether. He is the kind of man who came to the conclusion that there is nothing outside physical reality. Even if one believes that there might be 
something/someone beyond the physical realm, religion and its kind is still considered useless. The worst characteristic of such a man is that he is an unconscious materialist, besides the lesser problem that he is a practical person. According to Doan the problem of the unconscious materialist is that he gave up the conscious principle of materialism, and became one by 'commonplace exercises of his daily rounds of affairs' (Doan, 1909, p. 7). Religion set against the values of materialism does not result in the church being superior by default, but it does offer parallel values that can be evaluated (Butler, 1922, p. 22). The lack of any aspiring and poetizing art, which would offer them an insight into the unseen realm of human thought, keeps them indifferent towards culture. Doan classifies them as miserable, but he believes that the reality of their inner life is contrary to the practical applications of their indifferent minds. He explains that these people who conceal their terrible longing to the 'Eternal' (Doan, 1909, p. 7). Their desire to be in a veridic and authentic relation with the spiritual, makes them act in such a way as to revolt against the simplistic and meaningless way of life, characteristic to such unconscious materialists. The joy for Doan is that these men are coming together to change the church from that which is, into something more lively (Doan, 1909, p. 8).

Perhaps one of the truly sad issues that Doan marks is that the simple men, who have no theological background are more serious and more capable to understand the spiritual, than the clergy or the pastors. This conclusion proves to Doan that an honest quest for the inner impulse is not connected intrinsically to one's academic instruction. Being serious in matters of religion offers the upper hand. Religion takes a great amount of time in considering the serious arguments that allowed it to stay alive for millennia. Religion is also about sincere, honest thought (Finlay, 1917, p. 154). A minister who tries in desperation to be overtly apologetic, ends in tampering the sacred offices of religion. Such an approach towards religion will make the average man avoid the church altogether, due to the theatricality of the service. In other words, it will seem fake, processed, and artificial. Bowing before the deity of such a church is simply unacceptable. For Doan preaching is fundamental for the correct description of the spiritual and it is the proper means to draw people to it. Doan describes a good sermon a

'honest preaching, simple and abandoned, with nothing concealed or withheld between preacher and people; where there has been no timidity nor sensational clap-trap, but a free, unafraid and unashamed giving of his whole, honest and solemn person in the preacher's weekly meditation before his people; where there has been no apology nor nervous self-defense but simple and straight-forward reflection upon the eternal instincts and passions of life' (Doan, 1909, p. 9).

For Doan, the battle is given in the field of honesty towards one neighbor. The oration from the pulpit should be as natural as a discussion between friends in an informal context, provided the preacher is non-theatrical in every-day life as well. Some tend to put on a mask of seriousness and stoic resilience with regards to normal dialogue when engaged in debates on the spiritual or religion. His idea of correct and honest preaching is not idealistic. He does not dream of such a way of preaching, as if it had never happened before. Doan gives the example of Brooks, Beecher, Hale and others, but these are 'giants of God' who do not confront the indifferent laity (Doan, 1909, p. 9). It is this laity that must find a voice and guidance in the church. The cry of Doan is against the foolishness with which the church treated the non-clerical masses. It is here that Doan presents the idea of the 'Larger life', with reference to an engulfed present life by the spiritual/religious life. Preacher have lost their power to move people, partly due to the fact that they are not confronted by the practical aspects of life, as in the case of the layman, who can work out the issues better and easier (Doan, 1909, p. 10). Preaching can be a disaster and the 'smart, flippant, jocular is surely the words (Jackson, n.d., p. 208). Doan makes the brilliant point that a clergyman should stay as such, and in his debates with any layman he should not believe that he can win them over by becoming a layman himself. Am grotesque misunderstanding on the part of the preacher is not to understand one's place in the realms of the spiritual and the physical. According to Doan each has a well established purpose in life. The preacher must not know practically the issues that face the layman, in order to win one over, but the preacher should understand him by 'touching somehow each week, simply and solemnly, the things the layman himself in all his spiritual silence, modesty and sensitiveness' (Doan, 1909, p. 11). This is a challenge for the ages: the man thoroughly standing between two worlds, comes to understand those from one world, not by becoming them, but by understanding them.

The main issue that comes into conflict with, for example, the contemporary protestant environment, is related to what Doan calls the confused mind. This confusion is to be read in a negative connotation, as if the confused are not moral or secularized, or faithless in God or towards the congregation. Instead they are confused in comparison with Doan's set of beliefs. Therefore he mentions first the simple country ministers. He describes them in warm images, as men of faith, quiet and unobtrusive, fameless, but with a moral compass pointing accurately towards righteousness, where they lead their flock of believers. These men are connected intrinsically to the faith and teachings of their predecessors. They are men of 
valor, who have become gentler and more sensitive with regard to their fellow men. Doan's appreciation for such men stems from the fact that they argue their faith with a mystics conviction, but are also simple, untutored and unspoiled (Doan, 1909, p. 12). Their arguments and way of theological insight is borderline mystical. According to Doan, they are qualified to be rightfully in the direct line of apostolic succession. The fact that they are not spoiled by 'Christian Evidences' and 'Sacred Oratory' makes them think in lines of every day life needs (Doan, 1909, p. 12). The question could if the power of preaching is lost (McComb, 1910, p. 283), or whether it was kept safe by these honest, simple preacher. They look at the Bible, at the people in the pews and then they work their way to argue in such a simple and straight forward way, as to makes sense of the how and why God works in the world of humans. They do not have the skills of the highly educated, or the scientifically versed preacher. Instead they see the spiritual, the religious and the physical in the most sincere way.

These men have interacted with dogmas and they have certainly been subjected to their influence, but they were never able to understand them in their deepest significance. Hence they took what they understood. The lack of formal education prevented them to fully understand what doctrines contain. The people who listen to such a sincere preacher do not believe in God dogmatically, instead they look at the preacher, they know him, in time they come to trust him, and later they are willing to 'stake their own eternal lives' on his honor (Doan, 1909, p. 13). This is the case that Doan had made previously, when arguing that some preach truth as if it were fiction. Doan believes these preachers do this precise thing, but they are convinced that their fiction is truth, therefore that 'truth' is sacred and everlasting. Dogmatics, in this context, pose as impertinent elements that come against the inner conviction of man. The inner is of such strong build that they create their own doctrines, not too seldom, different from the original doctrines, which have the indestructible status of absolute truth. The problem that Doan remarks is that even if these people believe in God and their dogmas make sense for their religious experiences, they confuse the eternal values: 'belief in God, eternity, human destiny and the like' with their historic denomination (Doan, 1909, p. 13). In other words the values described in the previous phrase, according to Doan, are universally valid. They are believed by any man, on any continent, in any historical period, but the problem is that all paint the values in the colors of a certain religion or denomination or sect. By doing this, all these religious groups evaluate the rest of the world in the light of their personal/denomination absolute truth. If Doan argues that Christians do this for the eternal values that are experienced by all men, it would be safe to argue that all religious groups on in the world, in any historical period, did the same error, that all believed their view was the only correct one, thus ignoring the eternal religious values.

'Back to Christ' is a formula used by Doan to describe those preacher and honest intellectuals who tried to urge the believers to a dogmatic form of spirituality and religion, that aimed at seeing Christ as the sole owner and deliverer of truth, thus ignoring the eternal impulses of the spiritual realm. However, the problem is that these helpful intellectuals paid the 'price of intellectual confusion for the precious freight of practical goods conveyed to them within the wrappings of a former faith' (Doan, 1909, p. 14). The slogan 'back to Christ' is used in contemporary Evangelical circles, from pulpits, with the more or less precise argumentation according to which the foundation of true spirituality and the correct connection between God and the world is only through Jesus Christ, the only begotten Son of God, who was incarnate, died on the cross, rose three days later, and now sits at the right hand of God, being forever in the lives of every believer. Regardless of one's perspective on Christ, it is doubtless that the example set forth by Christ is of excellence in matters of morals (Torrey, 1910, p. 131). As Doan remarks the problem of this kind of speech is that it shifts almost instantly 'turns the corner from the essential to the unessential, from the spontaneous to the dogmatic, from the inner life to its external forms, from the eternal to the transient things of religion' (Doan, 1909, p. 14). For Doan dogmatized religion represents the fake and egotistic representation of the inner, original, true religious impulses that are within each human being. We, as a species, have these within us, but we cannot act upon them. For whatever reason, we would rather go after our formalized, fake and destructive dogmatic representation of the inner spiritual realm. The inner spiritual life is spontaneous, non-dogmatized and free from any unnecessary embellishment that reason can put forth. All external forms of the spiritual, which range from liturgy to church architecture, or to any other kind, are mere corruptions, which take away the attention from truth. Apparently man has truth within. This truth is not born within man, but man is connected to the eternal, by way of owns existence. Even if this inner cannot be fully comprehended, or fully understood, it can, however, be masked by doctrine and the external life. According to Doan, after two millennia, the original Christianity is to be found only in the early times, during the "early patristic Christianity' (Doan, 1909, p. 15).

The development of early Christianity is documented as being of simple liturgy, honest attempts to understand God and the development of dogma had a different pace and purpose, than after it became legalized. Justo Gonzales argues that Christianity was much simpler, due to political pressure and the threat of persecution. This context forced Christians to think 
their faith in simple and honest terms, because they could not afford the luxury of debates on unnecessary issues. The simplicity and honest faith - with the threat of persecution one had to be certain of one's faith - were replaced by the freedom and privileges offered by the new status, and to this politics were added (McGrath, 2010, p. 43).

If in the beginning Doan was marking the fact that many of the modern people are, in fact, true seekers of the spiritual, but under the guise of unconscious materialism, he continues the description of his fellow modern men by arguing that they are not average, not at all. Their mind pattern is oriented towards a genuine seeking of the spiritual. However, these modern minds are few, for most of them belong to the afore mentioned category of the confused (Doan, 1909, p. 22). In order to make things clear, Doan defines the modern man as the

'rare and sincerely open mind, the man conscious of himself in relation to a full modern culture, unbound by historic forms and terms; his openness is natural and unaffected; with his whole person and without turning back he faces the prospect ahead; his is a spirit of iron constitution, radical to the very marrow, finding ravishing joy in trying to the heights and valleys of being the wings of his spirit, apt to reject as artificial and restrictive the familiar terms and dogmas of the historic church, eager to follow the pursuits of science and philosophy - in a word, unafraid, unashamed and open minded' (Doan, 1909, p. 22).

Such a complex definition requires a careful examination. The historical context of one's life can create various reactions towards the issues one faces. We have all been accustomed to hear the elder say 'back in my day the kids/people were better, much more respectful and much more polite', while the young might say 'I should have been born in another age, not in this one'. Unlike such examples, the genuine modern man acknowledges his historical existence in a certain age. There is no rejection of the age and its values, but a conscious assessment of one's environment. The modern man will not look back in history with envy, but with a critical apparatus that would allow him to see things as they were. This action offers the possibility of filtering the values of the past from the evils of each age. The present age, or the age in which the modern man lives, will only have to benefit from his honest input. Overlooking the value of history can prove to be more deceitful, than looking back into what has been said with a critical eye (Butler, 1922, p. 107). The values will be judged and evaluated in such a way that it will bring value to the present age, and mark the future of the generations to come. The modern man will fit and integrate fully in the historical context he lives in. There are no regrets concerning the past, but there is no full rejection of history either. The will of such a man is aimed at the pure truth. However, this truth is not that of the church, or the doctrinal one. It is a truth that he searches on his own, with his own methods. There is a desire and a joy to seek out the new, the unexplored. In this context, the modern man does not look at the church for guidance, but looks beyond the veil of tradition. Therefore, if there is truth in science and philosophy, the modern man will accept it, without hesitation. The main characteristic of the modern man is that he does not have any fear of the new and of exploring the various elements that make up life. Coupled to this, the modern man will explore even if it means going against the traditions of a culture, including the tradition of the church. The final emphasis is that the modern man has an open mind. He explores everything, to the best of his abilities and acts in accordance to his own inner conscience, built on the critical assessment of all aspects of life.

Doan continues the ode to the modern man by describing him as an innovator and an undaunted explorer. The cynics and the sceptics are close behind, trying to push him down and stop his efforts to find truth. In spite of all barriers the modern man is 'clean and pure in his mind; eager and sensitive in his soul; searching always for a positive and honorable experience of things eternal' (Doan, 1909, p. 23). This is an important aspect about the modern man, because even if he accepts the challenges and the novelty of science, he does not reject the spiritual. There is a connection that he makes between these apparently opposite realm of knowledge. He not only accepts both, but he goes with philosophy as well. He is not radical against any of these three domains and he does not accept only one of them. The modern man seems to be better than the ones who accept only one of these three domains and rejects without any problems the other two.

Perhaps one of the most important aspects of modern man's spirituality is that he is not afraid of meeting God, or 'That he may yet call God' (Doan, 1909, p. 23). The modern man is not anti-God, anti-divinity kind of human being. He does not dismiss this possible reality, unless he has come to such a conclusion after a series of trials. However, as Doan believes the modern man is open to meet God and even 'stand silent and conquered' (Doan, 1909, p. 23). He will not question the God he meets, but once this happens he will accept the reality of His presence with an open mind. He will fully understand where he stands in relation to the divinity, to God, and he will understand that God means more than him, therefore he will no problem accepting the authority and power of this God. When such an encounter will take place, one might expect a rallying of the modern man to a certain religion or denomination. Doan argues against this. He believes that once modern 
man meets God, he will, by conviction and in all truth, not adhere to any historical religion. Even if he does accept any of them, he will never accept that denomination or religion as final. He will see God and the spiritual above and beyond any religion. The church divine authority will play a major role in understanding and accepting God as God with absolute authority (Finlay, 1917, p. 135).

\section{Conclusion: Spontaneity of Spirit}

At this point, Doan returns to the spontaneity of spirit. This is the element that, if understood and interiorized, will prevent modern man to allow the institutional religion to corrupt it. Doan points out that all institutional religions are inextricably connected to history in a negative way, by being full of 'past forms, myths, untruths and dead weight' (Doan, 1909, p. 23). The real problem with institutional religions is that they are made up of misleading formulations, that are able and willing to stop and spontaneity of spirit. This is the real danger for the modern man: allowing oneself to be brought down by forms of religion that go against his own convictions. Because he has an iron will, all these will be rejected by conviction. He will look at the eternal realities of religion with a peaceful heart. The reality of such spheres of knowledge will bring an insight into the realms of the outer and the inner man, in such a that will bring benefit to one's neighbor (Jackson, n.d., p. 160).

The idyllic picture of modern man is concentrated in a statement, according to which 'the modern man by temperament face ahead with his whole person. He is a bad historian and critic, if you please; an unloyal child of a long line of culture that bred him "modern"' (Doan, 1909, p. 24). It does not mean that the modern man will dismiss history and its heritage, but in least he is not connected consciously to the heritage. He is created by the culture of ages past, but he feels no connection to them. However, he claims them unconsciously. He is the product of the development of the ages, he sees the world around as the final product of the ages.

\section{Biblography}

Butler, F. W. (1922). Can We Dispense with Christianity? London: Student Christian Movement. Retrieved from https://archive.org/stream/canwedispensewit00butluoft\#page/134/mode/2up/search/authority

Doan, F. C. (1909). Religion and the Modern Mind. In Religion and the Modern Mind and Other Essays in Modernism. Boston, NY: Sherman, French \& Company. Retrieved from https://archive.org/stream/religionmodernmi00doanrich\#page/n5/mode/2up

Evans, D. (1911). The Ethics of Jesus and the Modern Mind. The Harvard Theological Review, 4, 418-438.

Finlay, P. (1917). Divine Faith. New York: Longmans, Green and Co. Retrieved from https://archive.org/stream/DivineFaith\#page/n163/mode/2up/search/church

Jackson, G. (n.d.). The Preacher and the Modern Mind (1912th ed.). London: Charles H. Kelly. Retrieved from https://archive.org/stream/thepreacherandth00jackuoft\#page/78/mode/2up/search/pulpit

Macbride Sterrett, J. (1922). Modernism in Religion. New York: The Macmillan Company. Retrieved from https://archive.org/details/modernisminreli00stergoog

Macculoch, C. (MCMVIII). Comparative Religion and the Christian Faith. In Religion and the Modern Mind. London: Hodder and Stoughton. Retrieved from

https://archive.org/stream/religionandmode00unkngoog\#page/n92/mode/2up/search/image

McComb, S. (1910). Christianity and the Modern Mind. New York: Dodd, Mead and Company. Retrieved from https://archive.org/stream/christianitymode00mcco\#page/n11/mode/2up

McGrath, A. E. (2010). Christian Theology: An Introduction. West Susex: John Wiley and Sons.

The Baptist confession of faith: first put forth in 1643; afterwards enlarged, corrected and published by an assembly of delegates (from the churches in Great Britain) met in London July 3, 1689; adopted by the association at Philadelphia September 22, 1742; and nowreceived by churches of the same denomination in most of the american colonies; to which is added, a short treatise of discipline. (1765). Philadelphia, PA: Ant. Armbruster. Retrieved from https://archive.org/details/confeo00phil 
The Quarterly Christian Spectator. (1833). New Haven: Stephen Cooke.

Torrey, D. (1910). Protestant Modernism: Or, Religious Thinking fo... Boston. Retrieved from https://archive.org/stream/protestantmoder00torrgoog\#page/n31/mode/2up/search/church 